UDC 342.951

DOI https://doi.org/10.32849/2663-5313/2021.11.08

Yaroslav Lazur,

Doctor of Law, Professor, Dean of the Faculty of Law, Uzhhorod National University, 26, Kapitulna street, Uzhhorod, Ukraine, postal code 88000,yaroslav.lazur@uzhnu.edu.ua

ORCID: orcid.org/0000-0002-7520-7167

Scopus ID: 57219772273

\title{
Oleksandr Bilash,
}

PhD in Law, Associate Professor at the Department of Administrative, Financial and Information Law, Uzhhorod National University, 26, Kapitulna street, Uzhhorod, Ukraine, postal code 88000, oleksandr.bilash@uzhnu.edu.ua

ORCID: orcid.org/0000-0002-1248-7798

Lazur, Yaroslav, Bilash, Oleksandr (2021). Public institute of environmental impact assessment. Entrepreneurship, Economy and Law, 11, 63-69, doi https://doi.org/10.32849/2663-5313/2021.11.08

\section{PUBLIC INSTITUTE OF ENVIRONMENTAL IMPACT ASSESSMENT}

Abstract. Purpose. The article deals with the study of the legal regulation of environmental impact assessment, and the express purpose is to substantiate the relevant administrative institute.

Research methods. Research methodology is stipulated by the article's purpose, and thus, both general and special methods of scientific cognition are used. The contribution involves addressing and studying the entities and subject of environmental impact assessment, the assessment procedure, as well as legal liability for the violation of statutory requirements. This structure of the study allows achieving the objectives set by the authors.

Results. The study of the legal regulation of environmental impact assessment allowed the authors to conclude that public-law institute is a set of rules specifying the entities and subject of impact assessment, the procedure for impact assessment, powers of authorized bodies and the rights and obligations of economic entities, appeals and control in the field of impact assessment. In particular, the entities entering into relevant legal relations are the Ministry of Environmental Protection and Natural Resource, regional, city Kyiv and Sevastopol state administrations, and their ecology and natural resources departments. The Law of Ukraine "On Environmental Impact Assessment" imperatively regulates the impact procedure, and all its stages are rendered in the Unified National Environmental Impact Assessment Registry to ensure transparency and public access. Criteria for specifying planned activities, the procedure for submitting comments, suggestions, conducting public hearings, financing of public discussion are imperatively regulated by the law and bylaws.

Conclusions. All mentioned in the article give grounds to argue about the formation and establishment of a new public-law institute of environmental impact assessment. It regulates public relations arising in assessing the adverse effects of the planned activity on the environment and human health, the development of measures designed to prevent, avert, avoid, reduce, eliminate such effects, and ensure the increase of positive influence.

Key words: impact assessment, environment, natural environment, planned activity, ecological expertise.

\section{Introduction}

The Constitution of Ukraine guarantees everyone the right to an environment that is safe for life and health. Everyone shall be guaranteed the right of free access to information about the environmental situation, the quality of foodstuffs and consumer goods, as well as the right to disseminate such information. At the same time, the Basic Law obliges everyone not to harm nature and compensate for the damage caused.
The ratified international acts determine the statutory regulation of environmental impact assessment: the UNECE Convention on Access to Information, Public Participation in Decision-Making and Access to Justice in Environmental Matters (the Aarhus Convention) ratified by the Law of Ukraine № 832-XIV dated 06.07.1999; Convention on Environmental Impact Assessment in a Transboundary Context (the Espoo Convention) ratified by the Law of Ukraine 
№ 534-XIV dated 19.03.1999; Protocol on Strategic Environmental Assessment to the Convention on Environmental Impact Assessment in a Transboundary Context (SEA Protocol) ratified by the Law of Ukraine № 562-VIII dated 01.07.2015; Association Agreement between the European Union and the European Atomic Energy Community and their member states, of the one part, and Ukraine, of the other part (UA-EU Association Agreement) ratified by the Law of Ukraine № 1678-VII dated 16.09.2014.

Branch laws, including administrative ones, elucidate and specify the relevant provisions of the Constitution and international acts. In particular, it also concerns the assessment of the adverse effects of the planned activity on the environment and human health, the development of measures designed to prevent, avert, avoid, reduce, eliminate such effects, as well as ensure the increase of positive influence. Therefore, the purpose of the article is to substantiate an individual public institute of environmental impact assessment within the framework of administrative law.

2. Entities and subject of impact assessment

At present, the obligation to assess environmental impact is one of the root principles of environmental protection under the provisions of the Law of Ukraine "On Environmental Protection". Environmental impact assessment is also one of the environmental protection tools (Malysheva et al., 2018). The immediate and obvious goal of assessment is to inform economic entities about the potential environmental implications of their actions, but environmental impact assessment is increasingly promoted in the broader context of sustainable development and its initial content - as a contribution to more sustainable forms of development (Jay et al., 2007).

In decision-making on economic activity, the special law "On Environmental Impact Assessment" № 2059-VIII dated 23.05.2017 regulates legal and organizational frameworks of environmental impact assessment focused on preventing environmental damage, maintaining environmental safety, environmental protection, rational use, and restoration of natural resources. However, the development of the relevant legislation has come a long way (Eremeeva, 2017). According to statutory provisions, the mentioned law de facto substituted the law "On Ecological Expertise" (case № 580/1078/19). The new legal institute of environmental impact assessment is more complex in content and procedure than the state environmental expertise (which it superseded); it covers a broader range of participants (Sydor, 2018, p. 145) and provides for detailed regulation of public debates and sanctions for violations of the legislation on environmental impact assessment. It sufficiently regulated the rights and obligations of individuals and the powers of authorities that became the blueprint for the progress of the relevant case law (Kovalenko, 2019; Digest of the case law of the Supreme Court, 2019).

As for the case law, the Digest of the practice of the Supreme Court in disputes arising in terms of environmental protection and environmental rights (Digest of the case law of the Supreme Court, 2019) attributes disputes over environmental impact assessment to a separate group of cases. This is primarily stipulated by the high risk of negative implications while implementing potential environmentally unfriendly activities and the mandatory consideration of findings such implications with the necessary and direct participation of the public.

The Law "On Environmental Impact Assessment" defines the following range of participants in legal relations: 1) a business entity or public authorities, local selfgovernment bodies, which are customers of planned activities and thus, their legal status is equated to business entities; 2) government entities: the authorized central body, authorized territorial bodies, other executive bodies, local self-government bodies; 3 ) the public; 4) the country of origin and the affected country.

The authorized central body is a central executive body, which ensures the formation and implementation of state policy on environmental protection - the Ministry of Environmental Protection and Natural Resources of Ukraine. Authorized territorial bodies are oblast, city Kyiv and Sevastopol state administrations: relevant units (departments) for ecology and natural resources, executive body for ecology and natural resources of the Autonomous Republic of Crimea.

The public is defined as one or more natural or legal persons, their associations, organizations, or groups. According to the Convention on Access to Information, Public Participation in Decision-Making and Access to Justice in Environmental Matters ratified by Ukraine, "the public" means one or more natural or legal persons, their associations, organizations or groups performing under national legislation or practice; "the public concerned" means the public affected or likely to be affected by, or having an interest in, the environmental decision-making; for the purposes of this definition, non-governmental organizations promoting environmental protection and 
meeting any requirements under national law shall be deemed to have an interest. The case law shows that the conventional definition is also taken into account by the courts when considering the relevant category of cases (case № 640/21828/18).

The Ministry of Environmental Protection and Natural Resources of Ukraine coordinates and provides environmental impact assessment and reports on environmental impact assessment. It also maintains the Unified National Environmental Impact Assessment Registry, the procedure for which is determined by the Decree of the Cabinet of Ministers of Ukraine № 1026 dated 13.12.2017. Information available on the website of the Unified National Environmental Impact Assessment Registry is open, and free access is via the Internet (Register of environmental impact assessment).

According to the Law "On Environmental Impact Assessment", there are two categories of activities and facilities, the initiation of which may have a significant impact on the environment and is subject to impact assessment:

1) oil and gas refineries, thermal power plants, and other facilities for the production of electricity, steam and hot water, nuclear power plants, metallurgical enterprises, chemical industry, construction of facilities (airports, aerodromes, highways, automobile roads, main railway lines of general use, hydraulic constructions, waste management, dams, quarries, surface mining operations, and other similar industries;

2) individual types and high production capacities in agriculture, forestry and water management, mining industry, energy industry, mineral processing, food industry, textile, leather, woodworking, and some infrastructure projects.

However, scientific literature contains viewpoints on the improper identification of the scope of environmental impact assessment and offers options for specifying the lists of activities which are subject to mandatory environmental impact assessment to improve its statutory regulation (Erofeev, 2021; Tretiak, 2016).

Impact assessment is obligatory to the planned activity, i. e., the activity which is being planned, before rendering the decision to carry out the activity, as its implementation is devoid of any meaning after taking such a decision. As a general rule, an assessment cannot be conducted towards activities which are already in progress. An exception comprises expansion and alterations, including revision or updating of the conditions of the planned activity established (approved) by the decision to carry out the planned activity or extension of its implementation, reconstruction, technical re-equipment, overhaul, reorientation of activities and facilities which are subjected to obligatory assessment.

In addition to statutory provisions, the Government Resolution "On Criteria for Determining Planned Activities Not Subject to Environmental Impact Assessment” № 1010 dated 13.12.2017, exercises the regulation of the scope of impact assessment.

3. Approval of environmental impact assessment

The statutory procedure of environmental impact assessment consists of several stages: 1) business entity's sharing informing with the authorized territorial body about the intention to carry out the planned activity; 2) the publication of a notice of planned activities subject to environmental impact assessment; $3)$ the announcement of the beginning of a public discussion of the impact assessment report; 4) ensuring that the business entity drafts an environmental impact assessment report; 5) the business entity's submission of a drafted report on environmental impact assessment and announcement of the beginning of its public discussion; 6) a public discussion in the process of environmental impact assessment; 7) the issuance of an opinion on environmental impact assessment by the authorized central or territorial body (Aleksyeyeva, 2018).

To gain transparency and public access, each of these stages is elucidated in the Unified Environmental Impact Assessment Registry. A registration file, involving the following components, is created in the registry: a notification of the planned activities subjected to environmental impact assessment; the request of the business entity to offer all essential requirements for the scope of examination; all public comments and suggestions on the planned activity, examination scope to be included in the report on environmental impact assessment; comments and suggestions of the authorized body; the announcement of the beginning of a public discussion of the environmental impact assessment report; environmental impact assessment report; a report on public discussion; information on the decision to carry out the planned activity; other documents related to the planned activity submitted by the business entity.

The business entity informs the authorized territorial body about the intention to carry out the planned activity and assess its environmental impact through submitting a notification. The authority records it into the Unified Environmental Impact Assessment Registry; 
during the next 20 working days, the public may provide the authorized territorial body with comments and suggestions on the planned activity, examination scope, and the level of information specification to be included in the environmental impact assessment report.

The business entity submits the environmental impact assessment report signed by its authors and the announcement of the beginning of report public to the authorized territorial body, and the latter enters the relevant report in the Unified Environmental Impact Assessment Registry, which keeps it throughout the planned activity, but not less than five years from the date of receipt of the decision to carry out the planned activity.

During environmental impact assessment, the public should be provided with timely, adequate, and efficient information in order to identify, collect, and take into account comments and suggestions from the public on planned activities. The public is free to submit any comments or suggestions which, in its opinion, relate to the planned activity without the need to justify them. Comments and suggestions may be submitted in writing, including in electronic form (in the manner prescribed by Article 7 of the Law of Ukraine "On Environmental Impact Assessment") and orally during public hearings, which are regulated by the Government Resolution on the Procedure for Conducting Public Hearings during Environmental Impact Assessment № 989 dated 13.12.2017.

A public discussion is funded by the business entity, and the amount of the charge is determined by the Order of the Ministry of Ecology and Natural Resources of Ukraine № 182 dated 30.05.2018. The charge covers expert services of members of expert commissions for environmental impact assessment, the organization of public hearings (rent of premises for public hearings, technical support of public hearings, business trips, the printing of materials, services of a public hearingorganizer, etc.) and conducting a public discussion following the procedure of transboundary impact assessments, other costs related to the deduction of Ministry of Environmental Protection and Natural Resources of Ukraine. The report on the public discussion is entered into the Unified National Environmental Impact Assessment Registry together with the statement on the environmental impact assessment.

The conclusion of environmental impact assessment determines admissibility or justifies the inadmissibility of the planned activity and lays down the environmental conditions for its implementation. The conclusion of environmental impact assessment and ecological conditions for conducting the planned activity are mandatory. Article 9 of the Law of Ukraine "On Environmental Impact Assessment" defines its content. The conclusion of environmental impact assessment, other decisions, actions, or omissions of public authorities or local governments may be challenged by any natural or legal person in court.

4. Liability for the violation of laws on environmental impact assessment

Persons guilty of violating laws on environmental impact assessment are held liable for disciplinary, administrative, civil, or criminal liability. Violations of environmental impact assessment mean the provision of knowingly false or incomplete information on the environmental impact of the planned activities; the violation of the established procedure for environmental impact assessment; failure to consider the findings of environmental impact assessment when deciding on the planned activities; the preparation of a knowingly false report on environmental impact assessment or a knowingly false conclusion on environmental impact assessment; illegal interference in the preparation and issuance of an opinion on environmental impact assessment; the implementation of the planned activities subject to environmental impact assessment without conducting such assessment and obtaining a decision on the planned activities; non-compliance during economic activities of the operation of facilities and other interventions into the natural environment and landscapes with ecological conditions defined in the conclusion on environmental impact assessment, the decision to carry out planned activities and projects of construction, expansion, reshaping, liquidation of facilities, other interventions in the environment and landscapes, changes in these activities, or extensionofterms(article15oftheLaw of Ukraine "On Environmental Impact Assessment", article 68 of the Law of Ukraine "On Environmental Protection").

According to article 91-5 of the Code of Ukraine on Administrative Offences, administrative liability means the provision of knowingly false or incomplete information on the environmental impact of planned activities, the violation of statutory requirements for environmental impact assessment, including the procedure for informing the public and conducting a public discussion and taking into account its results, as well as non-compliance during economic activity with the ecological conditions provided for in the conclusion on the environmental impact 
assessment, the decision on the planned activities and construction projects, expansion, reshaping, liquidation (dismantling) of facilities, other interventions in the environment and landscapes, as well as changes in this activity or extension of its terms.

Article 1729-2 of the Code of Ukraine on Administrative Offenses "Violation of Laws on Environmental Impact Assessment" in the chapter "Administrative offenses related to corruption" provides for the body of offenses, which can be violated only by officials. According to its provisions, administrative liability means the violation of the procedure and deadlines for environmental impact assessment, interference in the preparation and issuance of an opinion on environmental impact assessment or a decision to take into account the findings of transboundary environmental impact assessment, the refusal of a legally authorized territorial body, legally authorized central executive body to issue the conclusion on environmental impact assessment on grounds not established by law.

Another group of administrative offenses in this area comprises ones that are related to the violation of the right to information (Komarnytskyi, 2020). This refers to Article 212-3 "Violation of the Right to Information and the Right to Appeal" of Chapter 15 "Administrative offenses encroaching on the established management order".

Moreover, article 16 of the Law "On Environmental Impact Assessment” additionally sets such sanctions as temporary prohibition and cessation of the operation of enterprises or individual industries, as well as violations that may be grounds for the application of each of the sanctions. At the same time, the Supreme Administrative Court expressed the legal position that the response measure in the form of a complete cessation of works is an exceptional measure, the choice of which is possible if the identified violations pose a threat to life and/or health. In choosing such a response measure, the plaintiff as an authority and the court, respectively, must have regard to the principle of proportionality of the response measure to those violations that occurred and those that remained unsettled at the time of trial, as well as a guarantee of a fair balance between defendant's interests and the public interests (case № 807/1410/17). Thus, recourse to the court with claims to the business entity through suspending works shall be carried out in compliance with the principle of legal certainty following the provisions of Article 2 of SAC and after the expiration of the voluntary compliance with the order (case № 804/3983/18). Otherwise, the application of response measures, as an exceptional measure, by litigation is applied to all business entities that have been inspected and have violations that, in the opinion of the specially authorized body, pose a real threat to human life and/or health (case № 420/5235/18).

\section{Conclusions}

Therefore, the individual publiclaw institute is being formed in domestic legislation - the institute of environmental impact assessment, which may either occupy a separate place in special administrative law or become a part of natural resource law (Bilash, Karabin, 2021). The subject of the regulation of the institute of environmental impact assessment is public relations arising in assessing the adverse effects of planned activities on the environment and human health, developing measures to prevent, avert, avoid, reduce, and eliminate such effects, and enhance positive impacts. The institute's tasks are to regulate the procedure of environmental impact assessment clearly and properly that ensures openness and transparency, accessibility and public participation in decision-making, an approximation to EU acquis, and compliance with international agreements.

\section{References:}

Aleksyeyeva, Ye. (2018). Populyarnyy komentar do Zakonu Ukrayiny "Pro otsinku vplyvu na dovkillya" [Popular commentary to the Law of Ukraine "On Environmental Impact Assessment"] / ed. by O. Kravchenko. Lviv: Kompaniya "Manuskrypt” [in Ukrainian].

Bilash O., Karabin T. (2021). Umweltschutzrecht in der Ukraine [Environmental Protection Law in Ukraine]. OER Osteuropa Recht, 67(3), 335-352. Retrieved from: https://doi.org/10.5771/0030-6444-2021-3-335 [in German].

Case № 420/5235/18 of 27 October 2020: Resolution of the Supreme Administrative Court of Ukraine. Retrieved from: http://vasu.gov.ua [in Ukrainian].

Case № 580/1078/19 of 11 February 2021: Resolution of the Supreme Administrative Court of Ukraine. Retrieved from: http://vasu.gov.ua [in Ukrainian].

Case № 640/21828/18 of 4 December 2019: Resolution of the Supreme Administrative Court of Ukraine. Retrieved from: http://vasu.gov.ua [in Ukrainian].

Case № 804/3983/18 of 31 March 2021: Resolution of the Supreme Administrative Court of Ukraine. Retrieved from: http://vasu.gov.ua [in Ukrainian]. 
Case № 807/1410/17 of 11 September 2019: Resolution of the Supreme Administrative Court of Ukraine. Retrieved from: http://vasu.gov.ua [in Ukrainian].

Daydzhest sudovoyi praktyky Verkhovnoho Sudu u sporakh, shcho vynykayut u sferi zakhystu dovkillya ta ekolohichnykh prav (2019) [Digest of the case law of the Supreme Court in disputes arising in the field of environmental protection and environmental rights]. Retrieved from: https://supreme.court.gov.ua/userfiles/media/Daidjest_Ekologia.pdf [in Ukrainian].

Eremeeva, N. (2017). Problemy pravovoho zabezpechennya otsinky vplyvu na dovkillya [Problems of legal support of environmental impact assessment]. Ekonomika ta pravo - Economics and law, 1, 54-60 [in Ukrainian].

Erofeev, M. (2021). Sfera zastosuvannya otsinky vplyvu na dovkillya: pravovyy aspekt [Scope of environmental impact assessment: legal aspect]. Visnyk Luhanskoho derzhavnoho universytetu vnutrishnikh sprav imeni E.O. Didorenka - Bulletin of Luhansk State University of Internal Affairs named after E.O. Didorenko, 1(93), 213-232. Retrieved from: https://doi.org/10.33766/2524-0323.93.213-232 [in Ukrainian].

Jay, S., Jones, C., Slinn, P., Wood, Ch. (2007). Environmental impact assessment: retrospect and prospect. Environmental Impact Assessment Review, 27. pp. 287-300. Retrieved from: https://doi.org/10.1016/j.eiar.2006.12.001 [in Ukrainian].

Komarnytskyi, V. (2020). Administratyvna vidpovidalnist za pravoporushennya u sferi otsinky vplyvu na dovkillya [Administrative responsibility for violation of the impact on the environment]. Visnyk Luhanskoho derzhavnoho universytetu vnutrishnikh sprav imeni E.O. Didorenka - Bulletin of Luhansk State University of Internal Affairs named after E.O. Didorenko, 1(89), 162-172. Retrieved from: https://doi.org/10.33766/2524-0323.89.162-172 [in Ukrainian].

Kovalenko, N. et al. (eds.) (2019). Sudovyy zakhyst pryrodnoho dovkillya ta ekolohichnykh prav: mizhnarodnyy sudovyy forum [Judicial protection of the natural environment and environmental rights: international judicial forum ]. (Kyiv, November 7, 2019). Kyiv [in Ukrainian].

Malysheva, N., Tretiak, T., Shemshuchenko, Yu. (2018). Otsinka vplyvu na dovkillya yak instrument okhorony ekolohichnykh prav lyudyny [Environmental impact assessment as a tool for environmental protection]. LexInform (Yurydychni novyny Ukrayiny). Retrieved from: https://lexinform.com.ua/dumka-eksperta/otsinka-vplyvu-na-dovkillya-yak-instrument-ohoronyekologichnyh-prav-lyudyny/ [in Ukrainian].

Reyestr otsinky vplyvu na dovkillya [Register of environmental impact assessment]. Ofitsiynyy sayt Ministerstva zakhystu dovkilly a ta pryrodnykh resursiv Ukrayiny - Official site of the Ministry of Environmental Protection and Natural Resources of Ukraine. Retrieved from: http:// eia.menr.gov.ua/ [in Ukrainian].

Sydor, V. (2018). Otsinka vplyvu na dovkillya: zakon pratsyuye, problemy zalyshayutsya [Environmental impact assessment: the law works, problems remain]. Pidpryiemstvo, hospodarstvo $i$ pravo - Entrepreneurship, Economy and Law, 6, 142-146 [in Ukrainian].

Tretiak, T. (2016) Protsedura vyznachennya vydiv diyalnosti ta obyektiv, shcho pidlyahayut otsintsi vplyvu na dovkillya v Ukrayini [Procedure for determining the types of activities and facilities to be assessed for environmental impact in Ukraine]. Pravo i hromadianske suspilstvo - Law and civil society, 1, 112-127 [in Ukrainian].

\section{Ярослав Лазур,}

доктор юридичних наук, професор, декан юридичного факультету, Ужгородський начіональний університет, вулиия Капітульна, 26, Ужгород, Украйна, індекс 88000, yaroslav.lazur@uzhnи.еdи.иа ORCID: orcid.org/0000-0002-7520-7167

Scopus ID: 57219772273

\section{Олександр Білаш,}

кандидат юридичних наук, дочент, доцент кафедри адміністративного, фінансового та інформаційного права, Ужгородський національний університет, вуличя Капітульна, 26, Ужгород, Україна, індекс 88000, oleksandr.bilash@uzhnи.edu.иа

ORCID: orcid.org/0000-0002-1248-7798

\section{ПУБЛІЧНО-ПРАВОВИЙ ІНСТИТУТ ОЦІНКИ ВПЛИВУ НА ДОВКІЛЛЯ}

Анотація. Мета. Статтю присвячено дослідженню питань правового регулювання оцінки впливу на довкілля, а безпосередньою метою є обгрунтування відповідного окремого адміністративно-правового інституту. 
Методи дослідження. Методологія дослідження зумовлена метою роботи, тому використовуються як загальнонаукові, так і спеціальні методи наукового пізнання. Зміст дослідження полягає в опрацюванні та вивченні суб’єктів і предмета оцінки впливу на довкілля, власне процедури оцінки, а також юридичної відповідальності за порушення встановлених законодавчих вимог. Така структура дослідження дає змогу досягти завдань, що поставлені авторами.

Результати. Проведене дослідження правового регулювання оцінки впливу на довкілля дало змогу дійти висновку, що сукупність норм, які визначають суб'єктів і предмет оцінки впливу, процедуру проведення оцінки впливу, повноваження уповноважених органів та права й обов'язки господарюючих суб'єктів, оскарження та контроль у сфері оцінки впливу, є публічно-правовим інститутом. Зокрема, суб'єктами, які вступають у відповідні правовідносини, є Міністерство захисту довкілля та природних ресурсів України, а також обласні, міські Київська й Севастопольська державні адміністрації та їх підрозділи з питань екології і природних ресурсів. Процедура оцінки впливу імперативно регламентована Законом України «Про оцінку впливу на довкілля», для забезпечення прозорості та доступу громадськості всі їі етапи знаходять відображення в Сдиному реєстрі з оцінки впливу на довкілля. Критерії визначення планованої діяльності, порядок подання зауважень і пропозицій, проведення громадських слухань, фінансування громадського обговорення врегульовано імперативно законом та підзаконними актами.

Висновки. Усе викладене у статті в комплексі дає підстави говорити про формування та становлення нового публічно-правового інституту оцінки впливу на довкілля, предметом регулювання якого є суспільні відносини, що виникають у сфері оцінки негативних наслідків планованої діяльності для довкілля і здоров'я людини, а також розроблення заходів, спрямованих на запобігання, відвернення, уникнення, зменшення та усунення такого впливу, і забезпечення посилення позитивного впливу.

Ключові слова: оцінка впливу, довкілля, навколишнє природне середовище, планована діяльність, екологічна експертиза.

The article was submitted 15.11.2021

The article was revised 06.12.2021

The article was accepted 27.12.2021 